\title{
Et risikofritt liv?
}

\author{
En ung mor vant for en tid tilbake en sak i Oslo tingrett. Avgjørelsen reiser viktige spørsmål \\ angående informasjonsplikt og erstatningskrav i helsevesenet. På hvilket nivå skal man \\ legge opplysningsplikten?
}

Saken er som følger: Kvinnen ble under svangerskapet innlagt i sykehus på grunn av svangerskapsforgiftning. Hun ba om en kortvarig permisjon. Under permisjonen oppsto det morkakeløsning, noe som førte til at barnet fikk alvorlig hjerneskade. Kvinnen fikk korrekt informasjon om hva en pasient med svangerskapsforgiftning må passe på ved permisjon. Fordi hun mente hun ikke hadde fått informasjon om risikoen for morkakeløsning, søkte hun erstatning fra Norsk pasientskadeerstatning og deretter fra Pasientskadenemnda, men fikk avslag. Hun hevdet at hun, dersom hun hadde fătt informasjon om risikoen, ikke ville ha forlatt sykehuset og at keisersnittet da ville blitt utført tidligere - og gikk til sak mot Pasienskadenemnda. Dom har altså falt i Oslo tingrett, som har gitt kvinnen rett og tilkjent henne erstatning (1). Dommen er ikke rettskraftig, da den er anket.

Hvis man legger til grunn at risikoen for morkakeløsning i løpet av siste del av svangerskapet er $1,3 \%$, vil sannsynligheten for at dette skal inntreffe i løpet av en sekstimerspermisjon være ca. 0,004\%. Har helsepersonell plikt til å informere om en slik risiko? Hva er sannsynligheten for at fosterskaden ville vært unngått dersom kvinnen ikke hadde forlatt sykehuset? Den er i alle fall ikke $100 \%$. Hvor mye økte den aktuelle kvinnens risiko for å få et handikappet barn fordi hun tok permisjon? Det er ikke lett å si.

Pasienter har selvsagt rett til en rimelig grad av informasjon enten de er gravide eller har andre tilstander. Denne tragiske historien reiser imidlertid to prinsipielle spørsmål: Hvor langt skal informasjonsplikten gå? Har pasientene krav på erstatning der behandling gitt tidligere kunne ha redusert forekomsten av komplikasjoner?

\section{Risikoinformasjon}

Norske leger treffer daglig mange tusen beslutninger om medikamentbruk, medisinske undersøkelser, operasjoner og annen behandling. Alle disse innebærer en viss risiko for bivirkninger eller komplikasjoner. En allmenn plikt til å informere om risikoen også for sjeldne komplikasjoner innebærer flere utfordringer.

For det første er sannsynligheten når det gjelder de fleste komplikasjoner dårlig tallfestet. For det andre vil det være tidkrevende og kostbart for legene å informere om risikoen for alle typer komplikasjoner, inklusive de sjeldne. Om man antar at det treffes 50000 større og mindre beslutninger i løpet av en dag og at legen ved hver av disse skulle bruke to minutter på å informere om risikoen, utgjør dette i størrelsesorden 200 legestillinger. For det tredje er det veldokumentert at mange mennesker har problemer med å forstå sannsynligheter (2) - dette gjelder også dem med høyere utdanning. Typisk er det at de fleste overvurderer betydningen av forhold som innebærer lav sannsynlighet (3). En generell plikt til å informere om alle tenkelige komplikasjoner kan føre til at pasientene sier nei til tiltak som hadde vært $i$ deres egen interesse.

\section{Tidlig behandling}

Det er risiko for komplikasjoner ved mange sykdommer og tilstander, herunder hjerteog karsykdommer, diabetes, kreft, beinskjørhet og svangerskap. I løpet av et normalt svangerskap er risikoen for morkakeløsning i størrelsesorden $1 \%$ (4), men altså noe høyere ved svangerskapsforgiftning. Burde alle kvinner ha rett til å ligge i sykehus for å sikre tidlig keisersnitt i tilfelle morkakeløsning eller andre typer komplikasjoner i svangerskapet? En slik rett gir dessverre ingen garanti mot fosterskade. For kvinner som har hatt morkakeløsning, øker risikoen for at det samme skal skje i neste svangerskap, og risikoen er klart høyere enn hos en pasient med svangerskapsforgiftning (5). Disse pasientene blir i våre dager ikke innlagt i et nytt svangerskap fordi gevinsten ved dette er høyst tvilsom og ikke dokumentert.

Utfordringene kan også illustreres ved følgende eksempel. Utposning på livpulsåren forekommer hos $4-15 \%$ av dem over 65 år (6). Slike utposninger kan sprekke med store blødninger og høy risiko for å dø til følge. Dødeligheten vil være lavere dersom pasienten oppholder seg i eller ved sykehuset når blødningen inntreffer. Burde denne pasientgruppen ha rett til å bo på sykehotell ved siden av sykehuset dersom de ønsker det? Burde de pårørende få økonomisk erstatning dersom pasienten ikke får sitt ønske oppfylt? Her snakker vi om en pasientgruppe på mange tusen der den årlige sannsynlighet for alvorlig blødning er i størrelsesorden 1-5\%. Dersom vi skulle tilby 10000 pasienter permanent opphold i sykehotell til en daglig kostnad av kr 1000 , vil de årlige kostnader beløpe seg til 3,7 milliarder kroner. Dette eksemp- let er riktignok ekstremt, men antyder noe om hvor utviklingen kan bringe oss.

Advokaten i den omtalte rettssaken mener erstatningsdommen vil skape presedens. Hvis denne dommen blir stående, vil helsepersonell og pasienter komme i en håpløs situasjon få vil være tjent med. Det er ingen grunn til at gravide skal ha krav på mer informasjon enn andre. Konsekvensene av en utvidet plikt til å informere om enhver komplikasjonsrisiko kan dermed være betydelige både helsemessig og økonomisk. Det er riktignok grunn til å stille spørsmålet om norske pasiener får nok og riktig informasjon. Etter vår vurdering kan imidlertid en informasjonsplikt på det nivå den aktuelle dommen legger opp til, være i strid med pasientenes og samfunnets interesser. Har domstolen vurdert implikasjonene av den dommen den har avsagt? Ønsker samfunnet en allmenn rett til informasjon om komplikasjonsrisiko på dette nivået?

\section{Ivar Sønbø Kristiansen}

ivarsk@c2i.net

Avdeling for helseledelse og helseøkonomi

Universitetet i Oslo

Postboks 1089 Blindern

0317 Oslo

\section{Pål Øian}

Kvinneklinikken

Universitetssykehuset Nord-Norge

Oppgitte interessekonflikter: Ingen

\section{Litteratur}

1. Westerveld J. Mor vant over pasientskadenemnda. Aftenposten 3.1.2010: 4

2. Lipkus IM, Samsa G, Rimer BK. General performance on a numeracy scale among highly educated samples. Med Decis Making 2001; 21: 37-44.

3. Tversky A, Kahneman D. Judgment under uncertainty: heuristics and biases. Science 1974; 185 : 1124-31

4. Oyelese Y, Ananth CV. Placental abruption. Obstet Gynecol 2006; 108: 1005-16.

5. Rasmussen S, Irgens LM, Dalaker K. The effect on the likelihood of further pregnancy of placental abruption and the rate of its recurrence. $\mathrm{Br} \mathrm{J}$ Obstet Gynaecol 1997; 104: 1292-95.

6. Singh K, Bonaa KH, Jacobsen BK et al. Prevalence of and risk factors for abdominal aortic aneurysms in a population-based study : the Tromso Study. Am J Epidemiol 2001; 154: 236-44

Manuskriptet ble mottatt 22.2. 2010 og godkjent 14.5. 2010. Medisinsk redaktør Anne Kveim Lie. 